\title{
RESTORATIVE EFFECTS OF ZINGIBER OFFICINALE ON ARSENIC-INDUCED GENOTOXIC EFFECTS IN CHROMOSOMAL STRUCTURE OF MICE
}

\author{
SUMAN SHARMA, ANJALI SINGH GILL* \\ Department of Zoology and Environmental Sciences, Punjabi University, Patiala - 147 002, Punjab, India. Email: gillanjali3@gmail.com
} Received: 07 April 2018, Revised and Accepted: 19 May 2018

\begin{abstract}
Objective: The present study investigated the antigenotoxic effect of Zingiber officinale (Ginger) on arsenic-induced genotoxic effects in chromosome structure of Swiss albino mice.

Methods: Albino mice were divided into four groups: Group I was kept as control, Group II was administrated an oral dose of arsenic trioxide $5 \mathrm{mg} / \mathrm{kg}$ bw for 15 days, Group III was given an oral dose of arsenic trioxide $5 \mathrm{mg} / \mathrm{kg}$ bw followed by $20 \mathrm{mg} / \mathrm{kg}$ bw of ginger orally, and Group IV was administered with $20 \mathrm{mg} / \mathrm{kg}$ bw of ginger orally for 15 days and kept as positive control. The autopsies were done from all the groups on 15 -day posttreatment, and bone marrow was removed for chromosomal study and for calculating the frequency of micronuclei (MN).
\end{abstract}

Results: It is concluded from this study that long-term arsenic exposure causes chromosomal anomalies, for example, breaks, gaps, rings, stretching, and stickiness which leads to the fragmentation of chromosomes and increases the frequency of MN.

Conclusion: The administration of ginger showed modulatory effects against arsenic-induced genotoxicity.

Keywords: Arsenic (As), Chromosomes, Zingiber officinale, Genotoxicity.

(C) 2018 The Authors. Published by Innovare Academic Sciences Pvt Ltd. This is an open access article under the CC BY license (http://creativecommons. org/licenses/by/4. 0/) DOI: http://dx.doi.org/10.22159/ajpcr.2018.v11i7.26505

\section{INTRODUCTION}

Arsenic contamination in groundwater has become a worldwide problem. Currently, an unprecedented number of people in West Bengal, India, and Bangladesh are exposed to the ubiquitous toxicant through drinking water to the levels far exceeding the maximum recommended limit laid down by the World Health Organization (WHO). Keeping in view the health hazards, arsenic is one of the most important environmental toxicants, and it has become evident that increasing human activities have modified the natural cycle of metals and metalloids [1-3]. The risk of arsenic compounds has been elevated due to increasing human activities such as mining, smelting, and pesticide production which has led to the accumulation of arsenic in the soil [4]. The trivalent arsenite is more toxic than pentavalent arsenate. The trivalent form has higher affinity for thiol group, and it is more cytotoxic and genotoxic [5].

Exposure to arsenic causes both chronic and acute toxicity and is also evaluated as a human carcinogen [6,7]. The chronic exposure to arsenic causes various types of carcinogenic and non-carcinogenic health effects such as cancer of skin and internal organs, diabetes mellitus, hypertension, and respiratory conditions $[8,9]$.

Arsenic induces lipid peroxidation and thus acts as a prooxidant and also brings about protein and enzyme oxidation, glutathione depletion, DNA oxidation, and DNA adducts [10]. Arsenic leads to the formation of reactive oxygen species (ROS) like nitric oxide, which disturbs the poly ADP-ribosylation which is necessary for DNA repair, signal transduction, and apoptosis. As a result, arsenite induces DNA strand breaks and nicotinamide adenine diphosphate depletion [11]. Therefore, the genotoxic effects of arsenic compounds include induction of oxidative stress and inhibition of DNA repair. When generation of ROS overtakes the antioxidant defense of the cells, the free radicals start attacking the cell proteins, lipids, and carbohydrates, and this leads to a number of physiological disorders [12].
Inorganic arsenic metabolizes to dimethylarsenate which induces DNA damage and DNA single strand breaks as it inhibits repair polymerization $[13,14]$. The arsenic-mediated DNA protein interaction plays major role in carcinogenesis and induces protein-associated strand breaks which may provide explanation of chromosomal aberrations (CA) [15].

Natural phytochemicals hold a great promise in clinical therapy as they possess no side effects that are usually associated with chemotherapy or radiotherapy [16]. Medicinal plants are used for home remedies and are widely used in developed and developing countries. They are a diverse source of nutrients and bioactive compounds that are valuable for human health [17]. Plants and its products are being used as a medicine since long. Large number of phytochemicals is found in plant food [18]. Having a diet full of vegetables and fruits provide a large number of phytochemicals, antioxidants and nutritive products that boost our health. The natural dietary products such as various fruits, vegetables, and spices, which have drawn a great deal of attention from scientific community and the general public due to their various healthpromoting effects including suppression of cancers.

Zingiber officinale (Ginger) is a most widely consumed spice worldwide. It has a long history of use as a herbal medicine for the ailments for vomiting, pain, indigestion, and cold-induced syndromes $[19,20]$. Ginger is known for its antioxidant, anti-inflammatory, and anticancer activities [21]. The active components of the ginger are thought to be the volatile oils, and various phenolic compounds such as gingerols, shogaols, zingerone, and gingiberols [22,23]. Various authors have demonstrated strong antioxidant properties of ginger. The antigenotoxic action of ginger has been found as one of the possible mechanisms of oxygen free radical scavenging followed by decreased production of ROS [24,25]. Ginger rhizome contains two classes of constituents: (1) The essential oils which give the aroma and (2) the main pungent principles called gingerols [26]. 
In this study, the aqueous extract of $Z$. officinale (Ginger) was prepared to evaluate its antigenotoxic potential to combat arsenic trioxideinduced genotoxicity in albino mice.

\section{MATERIALS AND METHODS}

\section{Animals}

Swiss albino mice weighing $20 \pm 22$ g were procured from Central Research Institute, Kasauli. They were kept and acclimatized to the laboratory conditions for 15 days under optimal conditions of light and temperature. They had ad libitum access to tap water. The animals were handled with human care in accordance with the guidelines of the institutional animal ethical committee 107/99/CPCSEA/2013-03.

\section{Chemicals and preparation of extract}

Arsenic trioxide was bought from Qualikems Fine Pvt. Ltd., New Delhi. It was dissolved in double distilled water and administered orally to mice. Z. officinale (Ginger) was obtained from local market, and aqueous extract was prepared by the method of Ashraf et al. [27] and was also administered orally to mice.

\section{Experimental design}

The mice were divided into four groups of five mice each. Group I - control animals were given distilled water. Group II - animals were administered an acute dose of $5 \mathrm{mg} / \mathrm{kg}$ bw of arsenic orally for 15 days. Group III - animals were given an acute dose of $5 \mathrm{mg} / \mathrm{kg}$ bw of arsenic followed by a daily dose of $20 \mathrm{mg} / \mathrm{kg}$ bw of ginger for 15 days. Group IV - mice were administered $20 \mathrm{mg} / \mathrm{kg}$ bw of ginger orally for 15 days and kept as positive control. Autopsies were done on 15-day post-treatment.

1. The bone marrow cells of albino mice were examined for CA according to the method described by Preston et al. [28]. The animals were administered colchicine intraperitoneally for $2 \mathrm{~h}$ before dissection. At least 200 metaphases, plates were examined using research microscope with oil immersion lens.

2. Micronuclei $(\mathrm{MN})$ : Were evaluated by the procedure given by Elbin et al. [29].

3. Statistical analysis: The data were analyzed using Student's t-test using GraphPad by considering $p<0.001$ as significant and $p>0.05$ as non-significant.

\section{RESULTS AND DISCUSSION}

Arsenic is one of the most important global environmental toxicants. It induces ROS production which is known to affect cell signaling, apoptosis, increase in cytokine production, leading to inflammation and stimulation of more ROS production and mutagenesis, contributing to pathogenesis of arsenic-induced diseases [30].

The major targeting site of free radicals is genetic material carried by the cells. The types of damages include strand breaks (single or double strand breaks), various forms of base damage yielding products such as 8-hydroxyguanosine, thymine glycol or abasic sites, damage to deoxyribose sugar, as well as DNA protein cross-linkages [31]. These damages can result in inheritable mutations that can yield a cancer in somatic cells or fetal malformations in the germ cells. The involvement of free radicals with tumor suppressor genes and proto-oncogenes recommend their role in the development of different human cancers [32].

Genotoxicity occurs when large number of ROS reacts with both deoxyribose and bases in the DNA causing base lesions and structural breaks. The ROS species also alter the DNA repair mechanism species [33]. Arsenic toxicity causes oxidative

stress. The production of ROS by arsenic is also supported by scientific data, and this mode of action of the metal got acceptance $[34,35]$. During the present investigation, arsenic trioxide was observed to possess the genotoxic potential as revealed by statistically significant $(p<0.01)$ increase in various types of CA on 15 -day post-treatment in comparison to control group. Who reported that arsenic caused genotoxic and other ill health effects. The chromosomal abnormalities and MN were detected in the interphase cells of human population who were exposed to arsenic.

There are various types of CA which were studied in the four groups at 15-day post-treatment. Data of chromosomal assay were represented in Fig. 1. The frequency of ring chromosome $2 \pm 0.32$, loss of definite walls $1.2 \pm 0.37$, stickiness $1.2 \pm 0.37$, stretching $1.2 \pm 0.58$, and fragment $1.6 \pm 0.51$ in control group and the frequency of CA were lower in comparison to arsenic-treated group. In arsenic-treated group frequency of ring chromosome ring $8.2 \pm 0.37$, loss of definite walls $8 \pm 0.32$, stickiness $8.2 \pm 0.37$, stretching $8.6 \pm 0.24$, fragment $8.2 \pm 0.37$. Arsenic $+Z$. officinalis frequency of ring chromosome ring $5 \pm 0.32$, loss of definite walls $6.6 \pm 0.24$, stickiness $6 \pm 0.45$, stretching $7.8 \pm 0.37$, fragment $5.8 \pm 0.58$.

Z. officinalis frequency of ring chromosome ring $3.4 \pm 0.4$, loss of definite walls $3.2 \pm 0.2$, stickiness $3 \pm 0.32$, stretching $3.6 \pm 0.51$, fragment $2.6 \pm 0.24$. The dose of $Z$. officinale modified the arsenic trioxide-induced changes in MN.

Incidence and CA ring (Graph 1), loss of definite walls (Graph 2), stretching (Graph 3), stickiness (Graph 4) and fragmentation (Graph 5) multiple aberrations to a significant extent as compared to that of arsenic-treated group alone. A similar observation was found in the study of Nirmala et al. [36] who have reported the in vivo antimutagenic potential of ginger on formation and excretion of urinary mutagens in rats using an in vitro assay method.

In the present study, CAs, for example, the chromosomal breaks, ring, and other multiple aberrations such as fragmentation, stretching, stickiness, and loss of definite walls were found to be significantly increased in arsenic-treated group. The studies on human fibroblast cells, leukocytes, lymphocytes, and hamster cells which indicated that the arsenic is highly toxic and caused genotoxic effects on the chromosomes, i.e. CAs and sister chromatid exchange [37]. Various studies done on humans suggest that CAs were maximum in peripheral lymphocytes of humans after both the inhalation and oral exposures. In our study, we observed that CA and the genotoxic effects increase in mice with increase in duration of exposure to arsenic.

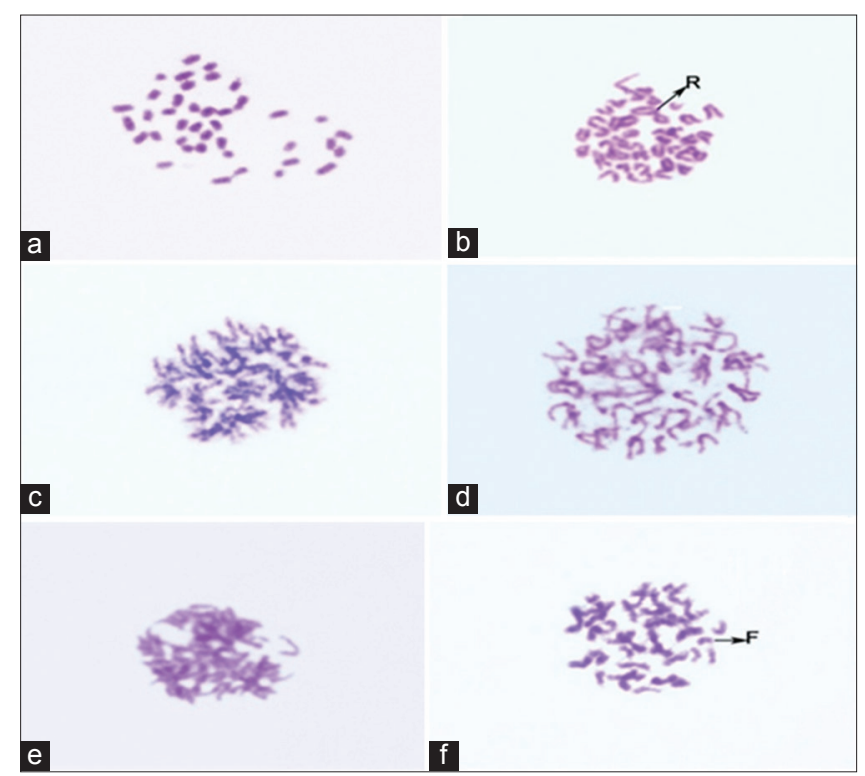

Fig. 1: A photomicrograph of metaphase spread chromosome in bone marrow of albino mice showing the modulatory effect of ginger on arsenic-treated mice for 15-day post-treatment: (a) Control, (b) ring, (c) loss of definite wall, (d) stretching, (e) stickiness, (f) fragment 


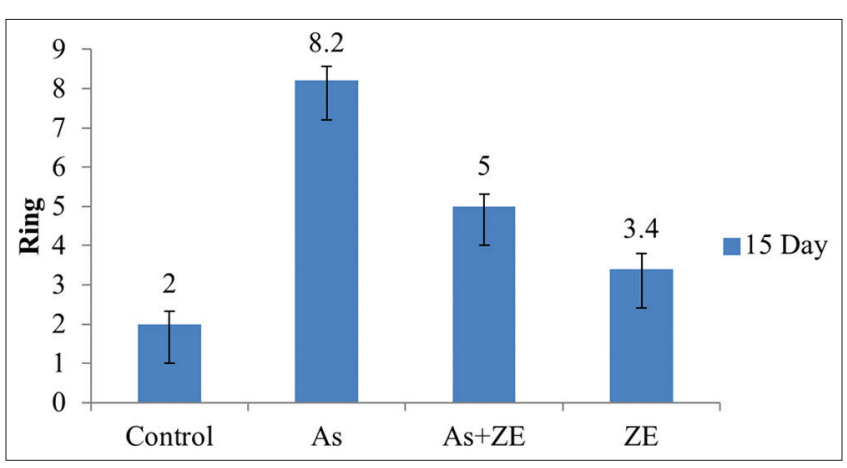

Graph 1: Chromosomal aberrations (ring) in control, arsenic, antioxidant, and positive treated mice at 15-day post-treatment

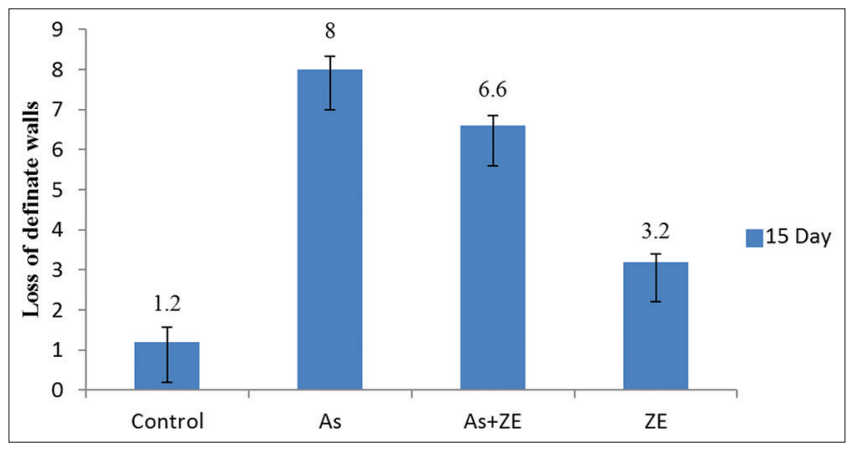

Graph 2: Chromosomal aberrations (loss of definite walls) in control, arsenic, antioxidant, and positive treated mice at 15-day post-treatment

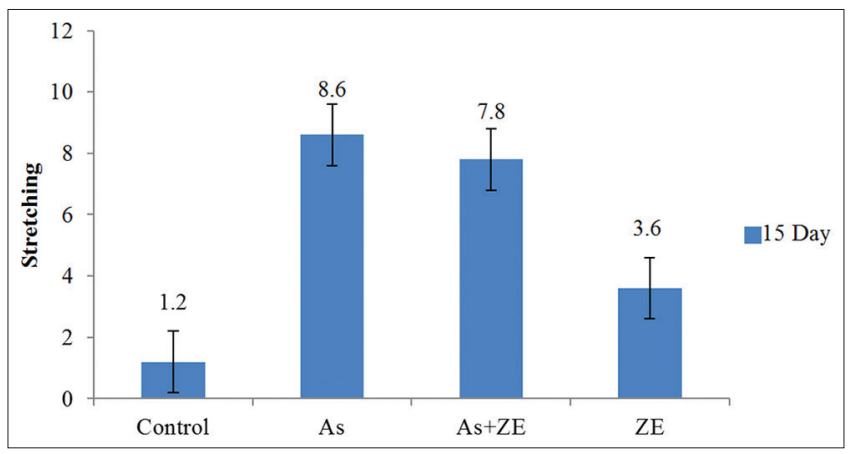

Graph 3: Chromosomal aberrations (stretching) in control, arsenic, antioxidant, and positive treated mice at 15-day posttreatment

In this study, some of the metaphase plates demonstrated the sticky behavior of chromosomes because they stick to each other at definite places. Some showed the fusion of acrocentric chromosomes that resulted in the formation of metacentric chromosomes and few foci showed telomeric fusion which ultimately formed ring chromosomes. Various chromosomes showed centromeric separation of chromatids as well as chromatid breaks. The fragmented chromosomes were also studied in which arms contained less dense telomeres which confirmed the early loss of genes residing at the telomeric ends and are responsible for the cellular stress including ageing [23].

Z. officinale (Ginger) has been reported as an antioxidant agent $[38,39]$ due to its antioxidant properties and free radical scavenging characteristic and thus it is suited for metal chelation $[40,41]$. The results of the present study also highlight the beneficial potential of ginger and thus can be used as a nutrient supplement in heavy metal toxicity due to its tremendous antioxidant properties. Gingerol

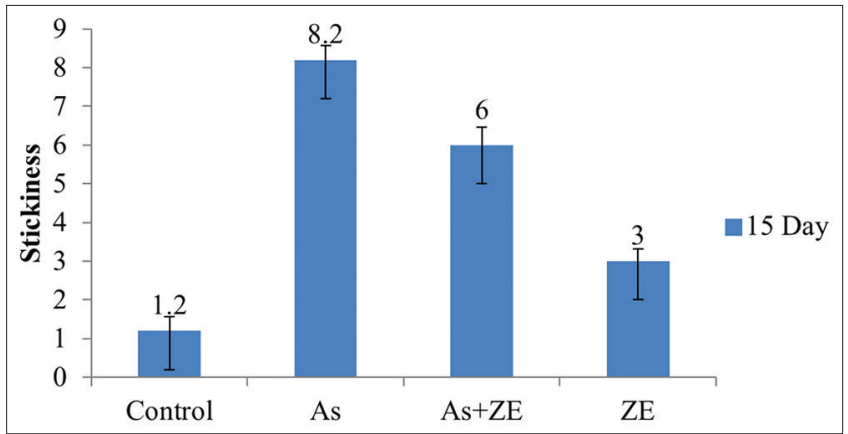

Graph 4: Chromosomal aberrations (stickiness) in control, arsenic, antioxidant, and positive treated mice at 15-day posttreatment

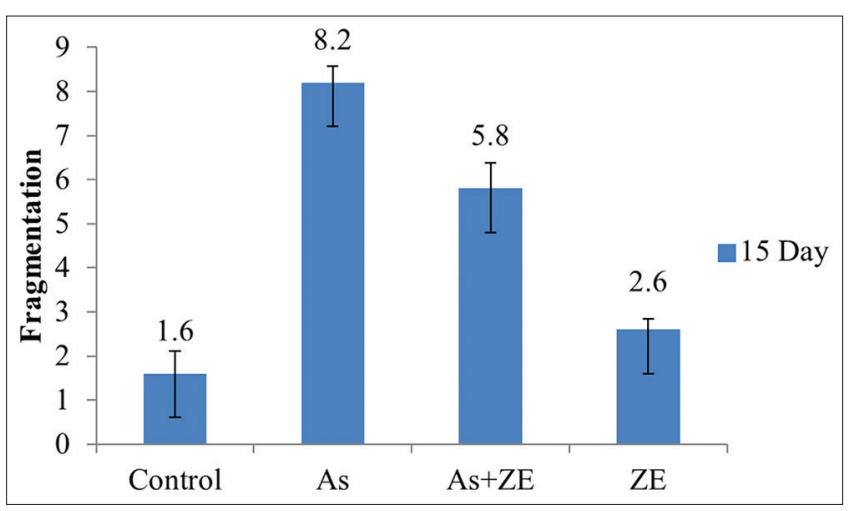

Graph 5: Chromosomal aberrations (fragmentation) in control, arsenic, antioxidant, and positive treated mice at 15-day posttreatment

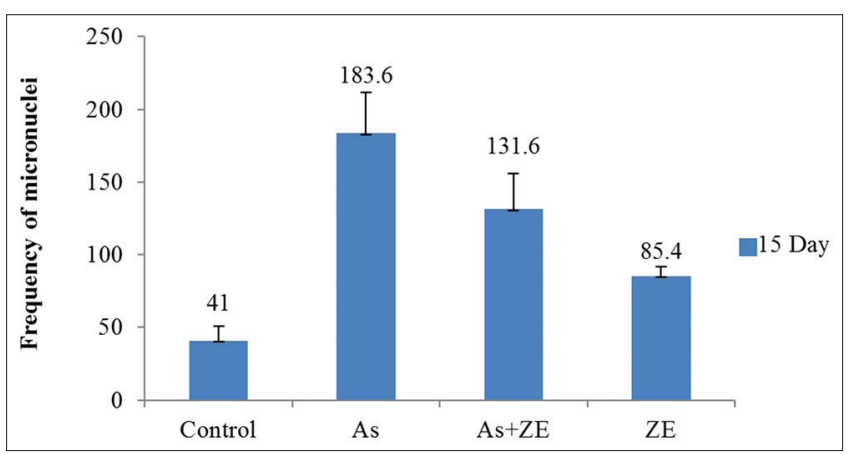

Graph 6: Frequency of micronuclei at 15-day post-treatment

was very effective in lowering the genotoxic effects [42]. Similarly, Sharif [43] reported genoprotective and hepatoprotective activities of ginger against carbon tetrachloride toxicity. Various studies made with ginger supplementation revealed that ginger acts as antimutagenic agent against carcinogenic activities in vivo and in vitro studies and is effective in reducing the genotoxic effects and DNA damage [44].

The MN test confirmed chromosomal damage as well as disturbance in mitotic spindle apparatus (clastogenic or aneugenic effect) in polychromatic erythrocytes in bone marrow. MN are cytoplasmic chromatin containing bodies formed in bone marrow erythroblasts. During the maturation process, the erythroblast develops into a polychromatic erythrocyte; the nucleus undergoes extrusion and MN persisting in enucleated cytoplasm can be detected using specific staining processes. The mean value of MN in control group was $41.00 \pm 9.74$ and in arsenic-treated group was $183.4 \pm 27.74$ which showed a statistically significant $(\mathrm{p}<0.01)$ elevation in comparison to 
control group. The frequency of $\mathrm{MN}$ in Arsenic+ Z. officinale treated group was $131.6 \pm 24.06$ and in $Z$. officinale was $85.40 \pm 6.10$ both showed statistically significant elevation in comparison to control group and showed non-significant increase in comparison to arsenictreated group. The MN frequency in bone marrow of mice coexposed to arsenic and benzopyrene [5].

The rat micronucleus method was used to detect the genetic toxicity in vivo. The micronucleus test in rodents (rats and mouse) is available in mammalian test system for detection of CAs [45].

In the present study, the CAs and MN frequency was observed to be significantly increased in arsenic-treated group in comparison to control and ginger-treated group. On the other hand, no significant difference was found in CAs in the group treated with only Z. officinale (Ginger) as compared to control group.

The data generated from this present study clearly indicate a significant increase in the MN frequency in arsenic-treated group in comparison to other treated groups; it is confirmed with the work of Dulout et al. [46]. Similarly, reported that the elevation in the number of MN frequency in polychromatic and non-chromatic erythrocytes serve as an index of chromosomal damage [47]. According to Patlolla and Tchounwou [48], MN test is more reliable test than CAs or sister chromatid exchange. Previous studies showed that arsenic-induced MN quickly in mice after administration of high doses of arsenic [44,49]. The induction of MN after exposure to $\mathrm{As}_{2} \mathrm{O}_{3}$ in our study was found to be dose dependent which is in accordance with the earlier published studies [50,51]. Both CAs and MN are genotoxicity markers [52-57]. Although their presence does not lead to adverse effects, their high-level indicates that cell has been exposed to the carcinogens. However, the biochemical alterations modulate the expression of growth control genes which are important in carcinogenesis or apoptosis [58].

\section{CONCLUSION}

Thus, in our in vivo study, Z. officinale (Ginger) possessed antigenotoxic effect along with antioxidant activity in albino mice. The regular consumption could be beneficial to counteract the adverse effects by enhancing antioxidant defense mechanism and neutralizing the toxic effect of ROS generated by the genotoxicants that are present in the environment. More research studies on other genotoxic models are suggested to establish the role of $Z$. officinale (Ginger) against the genotoxicants.

\section{AUTHOR'S CONTRIBUTIONS}

Anjali Singh Gill: Interpretation of data, drafting of report, and approval of the version to be published. Dr. Suman Sharma: Interpretation of data, drafting of report, and approval of the version to be published.

\section{ACKNOWLEDGMENT}

The authors gratefully acknowledge the facilities provided by the Department of Zoology and Environmental Sciences, Punjabi University, Patiala, to pursue the research work. Furthermore, the financial aid extended by University Grant Commission in the form of Rajiv Gandhi National Fellowship for minority students is greatly appreciated.

\section{CONFLICTS OF INTEREST}

The authors declare that there are no conflicts of interest.

\section{REFERENCES}

1. Chowdhary R, Dutta A, Chaudhuri S, Sharma N, Giri A, Chaudhuri K. In vitro and in vivo reduction of sodium arsenite induced toxicity by aqueous garlic extract. Food Chem Toxicol 2008;19:105-12.

2. Alarifi SA, Alkahtani FM, Abou-tarboush, Al-qahtani A. Effect of DNA hypomethylation on genotoxicity and apoptogenicity of sodium arsenite in laboratory mice. Pak J Biol Sci 2009;12:554-64.
3. Raghu KG, Cherian OL. Characterization of cytotoxicity induced by arsenic trioxide (a potent anti-APL drug) in rat cardiac myocytes. J Trace Elements Med Biol 2009;23:61-8.

4. Toribio M, Romanya J. Leaching of heavy metals ( $\mathrm{Cu}, \mathrm{Ni}$ and $\mathrm{Zn})$ and organic matter after sewage sludge application to Mediterranean forest soils. Sci Total Environ 2005;363:11-21.

5. Patlolla AK, Todorov TI, Tchounwou PB, Voet GV, Centeno JA. Arsenic-induced biochemical and genotoxic effects and distribution in tissues of Sprague-Dawley rats. Microchem J 2012;105:101-7.

6. Brown EJ, Button DK. A simple method of arsenic speciation. Bull Environ Contam Toxicol 1979;21:37-42.

7. Tsuda $\mathrm{T}$, Babazono A, Yamamoto E. Ingested arsenic and internal cancer: A historical cohort study followed for 33 years. Am J Epidemiol 1995;141:198-9.

8. Mazumder DN, Haque R, Ghosh N, De BK, Santra A, Chakraborti D, et al. Arsenic in drinking water and the prevalence of respiratory effects in west bengal, India Int J Epidemiol 2000;29:1047-52.

9. Milton AH, Hasan Z, Rahman M. Chronic arsenic poisoning and respiratory effects in Bangladesh. J Occup Health 2001;43:136-40.

10. Lynn S, Lai HT, Gurr JR, Jan KY. Arsenite retards DNA break rejoining by inhibiting DNA ligation. Mutagenesis 1997;12:353-58.

11. Lynn S, Shiung JN, Gurr JR, Jan KY. Arsenite stimulates poly (ADP ribosylation) by generation of nitric oxide. Free Radical Biol Med 1998;24:442-49

12. Yamanaka K, Hayashi H, Tachikawa M, Kato K, Hasegawa A, Oku N, et al. Metabolic methylation is a possible genotoxicity-enhancing process of inorganic arsenics. Mutat Res 1997;394:95-101.

13. Sutar RC, Kalaichelvan VK. Evaluation of antioxidant activity of leaf extracts of Holoptelea integrifolia (roxb) Planch. Int J App Pharm 2014;6:6-8.

14. Hartwig A, Groblinghoff UD, Beyersmann D, Natarajan AT, Filon R, Mullenders LH, et al. Interaction of arsenic(III) with nucleotide excision repair in UV-irradiated human fibroblasts. Carcinogenesis 1997; 18:399-405.

15. Uong JI, Luo XM. Mutat Res 1993;302:97-102.

16. Rima T, Narasu ML. Evaluation of cytotoxic and genotoxic effects of zerumbone on colon adenocarcinoma colo205 cells and human lymphocytes. Int J Pharm Pharm Sci 2017;9:92-6.

17. Saravanan V, Murugan SS, Rajkumar JS, Krishnan KR. Evaluation of genotoxic effects of alcoholic extract of Kalanchoe pinnata Using Single Cell Gel Electrophoresis. Asian J Pharm Clin Res 2018;11:90-3.

18. Lampe JW. Health effects of vegetables and fruit: Assessing mechanisms of action inhuman experimental studies. Am J Clin Nutr 1999;70:475-90.

19. Wang WH, Wang ZM. Studies of commonly used traditional medicine ginger. Zhongguo Zhong Yao Za Zhi 2005;20:1569-73.

20. White B. Ginger: An overview. Am Fam Phys 2007;75:1689-91.

21. Shukla Y, Madhulika S. Cancer preventive properties of ginger: A brief review. Food Chem Toxicol 2007;45:683-90

22. Altman RD, Marcussen KC. Effects of a ginger extract on knee pain in patients with osteoarthritis. Arthritis Rheum 2001;44:2531-38.

23. Surh YJ. Molecular mechanisms of chemo preventive effects of selected dietary and medical phenolic substances. Mutat Res 1999;428:305-27.

24. Shimada T. Xenobiotic-metabolizing enzymes involved in activation and detoxification of carcinogenic polycyclic aromatic hydrocarbons Drug Metab Pharmacokinet 2006;21:257-76.

25. Sajwicz W. Toxicity of pyrimidine derivatives under oxidative stress conditions: Chemiluminescence based assays in systems containing erythrocytes, mitochondria or blood plasma. Pharmacol Rep 2007;59:206-15

26. Hussein MA. The effect of Zingiber officinalis aqueous extract on some biochemical parameters and kidney function in male mice. Kufa Med J 2012;15:273-8.

27. Ashraf K, Sultan S, Shah, SA. Phychemistry, phytochemical, pharmacological and molecular study of Zingiber officinale roscoe: A review. Int J Pharm Pharm Sci 2017;9:8-16.

28. Preston RJ, Dean BJ, Galloway S, Holden H, Mcfee AF, Shelby M. Mammalian in vivo cytogenetic assays: Analysis of chromosome aberrations in bone marrow cells. Mutat Res 1987;189:157-65.

29. Elbin KE, Bowen ME, Cromey DW. Arsenite and monomethylarsonous acid generate oxidative stress response in human bladder cell culture. Toxicol Appl Pharmacol 2006;217:7-14.

30. Ramana CV, Boldogh I, Izumi T, Mitra S. Activation of apurinic/ apyrimidinic endonuclease in human cells by reactive oxygen species and its correlation with their adaptive response to genotoxicity of free radicals. Proc Natl Acad Sci U S A 1998;95:5061-6.

31. Zhou Y, Lee AS. Mechanism for the suppression of the Mammalian stress response by genistein, an anticancer phytoestrogen from soy. 
J Natl Cancer Inst 1998;90:381-8.

32. Anterpreet C, Adesh KS, Anil KC, Reena VS. Natural antioxidants as defense system against cancer. Asian J Pharm Clin Res 2018;11:38-44.

33. Yamanaka K, Hasegawa A, Sawamura R, Okada S. Cellular response to oxidative damage in lung induced by the administration of dimethylarsinic acid, a major metabolite of inorganic arsenics, in mice. Toxicol Appl Pharmacol 1991;108:205-13.

34. Aflanie I, Muhyi R, Suhartono E. Effect of heavy metal on malondialdehyde and advanced oxidation protein products concentration: A focus on arsenic, cadmium, and mercury. J. Med Bioeng 2015;4:1-6.

35. Helleday T, Nilsson R, Jenssen D. Arsenic [III] and heavy metal ions induce intrachromosomal homologous recombination in the hprt gene V79 Chinese hamster cells. Environ Mol Mutagen 2000;35:114-22.

36. Nirmala K, Prasanna T, Krishna Polasa K. In vivo antimutagenic potential of Zinger on formation and excretion of mutagensin rats. Int $\mathrm{J}$ Canc Res 2007;3:134-42.

37. Kumar R, Gahlot V, Ali M, Akhtar S, Kumar A. Genotoxic effect of arsenic on chromosome structure of mice. Eur J Pharm Med Res 2016;3:224-7.

38. Vimala S, Norhanom AW, Yadav M. Anti-tumor promoter activity in Malaysian ginger rhizome used in traditional medicine. Br J Cancer 1999;80:110-16.

39. Sultana S, Ripa FA, Hamid K. Comparative antioxidant activity study of some commonly used spices in Bangladesh. Pak J Biol Sci 2010;13:340-43.

40. Haleagrahara N, Jackie T, Chakravarthi S, Rao M, Kulur A. Protective effect of Etlingera elatior (torch ginger) extract on lead acetate-induced hepatotoxicity in rats. J Toxicol Sci 2010;35:663-71.

41. Al-Sharif MM. Effect of therapeutic ginger on genotoxic of taxol drug (Anti-cancer) in bone marrow cell of male mice. J Lif Sci 2011;5:897-905.

42. Abd-Allah GA, El-Bakry KA, Bahnasawy MH, El-Khodary E. Protective effects of curcumin and ginger on liver cirrhosis induced by carbon tetrachloride in rats. Int J Pharm 2016;12:361-9.

43. Sharif AZ. Effect of therapeutic ginger on genotoxic of taxol drug (AntiCancer) in bone marrow cell of male mice. J Life Sci 2011;5:897-905.

44. Lewinska D, Arkusz J, Stanczyk M, Palus J, Dziubaltowska E, Stepnik M. Comparison of the effects of arsenic and cadmium on benzo (a) pyrene induced micronuclei in mouse bone marrow. Mutat Res Genet Toxicol Environ Mutagen 2007;623:37-43.

45. Kumar SM, Unnikrishnan MK, Devi UP. Effect of 5-aminosalicyclic acid on radiation induced micronuclei in mouse bone marrow. Mutat Res 2003;527:7.
46. Dulout FN, Grillo CA, Seoane AI, Maderna CR, Nilsson R, Vahter $\mathrm{M}$, et al. Chromosomal aberrations in peripheral blood lymphocytes from native Andean women and children from northwestern Argentina exposed to arsenic in drinking water. Mutat Res 1996;370:151-8.

47. Morita T, Asano N, Awogi T, Sasaki YF, Sato S, Shimada H, et al. Evaluation of the rodent micronucleus assay in the screening of IARC carcinogens (groups 1,2A and 2B) the summary report of the $6^{\text {th }}$ collaborative study by CSGMT/JEMS MMS. Collaborative study of the micronucleus group test. Mammalian mutagenicity study group. Mutat Res 1997;391:259-67.

48. Patlolla AK, Tchounwou PB. Cytogenetic evaluation of arsenic trioxide toxicity in Sprague Dawley rats. Mutat Res 2005;587:126-33.

49. Pashin IV, Kozachenko VI, Toroptsev SN. Arsenic trioxide inhibition of the thiophophamide induction of mutations in mouse germ and somatic cells. Genetika 1984;20:365-66.

50. Deknudt G, Leonard A, Arany J, Jenar-Du-Buission G, Delavinette E. In vivo studies in male mice on the mutagenic effects of inorganic arsenic. Mutagenesis 1986;1:33-4.

51. Miller WH, Schipper HM, Lee JS, Singer J, Waxman S. Mechanisms of action of arsenic Trioxide. Cancer Res 2002;62:3893-903.

52. Bonassi S, Hagmar L, Stromberg U, Montagud AH, Tinnerberg H, Forni A, et al. Chromosomal aberrations in lymphocytes predict human cancer independently of exposure to carcinogens. Cancer Res 2000;60:1619-25.

53. Liou SH, Lung JC, Chen YH, Yang T, Hsieh LL, Chen CJ, et al. Increased chromosome-type chromosome aberration frequencies as biomarkers of cancer risk in a Blackfoot endemic area. Cancer Res 1999;59:1481-4.

54. Martinez V, Creus A, Venegas W, Arroyo A, Beck JP, Gebel TW, et al. Micronuclei assessment in buccal cells of people environmentally exposed to arsenic in northern Chile. Toxicol Lett 2005;155:319-27.

55. Chakraborty TD. Clastogenic effects of inorganic arsenic salts on human chromosomes in vitro. Drug Chem Toxicol 2009;32:169-73.

56. Salazar AM, Sordo M, Ostrosky-Wegman P. Relationship between micronuclei formation and p53 induction. Mutat Res 2009;672:124-8.

57. Martinez V, Creus A, Venegas W, Arroyo A, Beck JP, Gebel TW, et al. Evaluation of micronucleus induction in a Chilean population environmentally exposed to arsenic. Mutat Res 2004;564:65-74.

58. Tchounwou PB, Centeno JA. Toxicologic Pathology. In: Gad SC, editor. Preclinical Development Handbook. New York: John Wiley \& Sons; 2008. p. 551-80. 